\title{
Aspects Regarding the Online Consumer Profile and the Impact on the Purchasing Behaviour
}

\author{
Oana PRICOPOAIA ${ }^{\star}$, Mihai CADINOIU ${ }^{\star \star}$, Adriana MATEI ${ }^{\star \star \star}$
}

\begin{tabular}{l}
\hline \multicolumn{1}{c}{ A R T I C L E I N F O } \\
\hline Article history: \\
Accepted August 2020 \\
Available online August 2020 \\
\hline JEL Classification \\
D12, M31 \\
Keywords: \\
Consumer, Purchasing behaviour, \\
Online environment, Decision, \\
Choice \\
\hline
\end{tabular}

\begin{abstract}
A B S T R A C T
In the online environment the consumer gets information on his own, looks for the desired product and compares features faster. The connection with brands is easier to create, and any opinion matters, so it is very important to manage all reactions, especially negative ones. Online, the aspects regarding the site structure and content, the page loading time, and the graphics are all elements influencing the decision to make a purchase from that site. The subjective factors such as: the fear the stock is not available, the fear to lose, receiving a free item, the idea of fast gain, turning a dream into reality, are all used in marketing campaigns to lead to the fastest completion of the online acquisition.
\end{abstract}

(C) 2020 EAI. All rights reserved.

\section{Introduction}

The buyer is not necessarily the final consumer, the buyer is the one concluding the purchase, and the consumer is the one using the product. In the online environment it is much simpler to promote what you want to sell, and objections and complaints can be solved faster and easier.

As technology advances, customers desire to get access to as much information as possible, and the company which will be successful should be available $24 / 7$. What matters in the online environment is: the comfort of the purchase, the cost incumbent to the customer, his experience and its assessment.

Online applications provide opportunities to the company, as well as the customer. The company will sell more, and the customer will get access to products more readily, as the orders are taken faster. In the era of smartphones with a permanent internet connection, online purchases ensure comfort, with no more trips to shops, and the search time becomes shorter.

In the online environment price is transparent, and the competition between companies selling the same or similar products is obviously stronger than offline. In this case the edge comes from aspects related to: site, easiness in acquiring the desired product, the service of customer care and return policy [Epuran, Gheorghe; Bianca Tescașiu, Raluca Dania Todor, Karin-Andreea Sasu, Nicoleta Cristache, 2017].

\section{Decision making in online purchases}

The purchase decision is final after the completion of several stages; first, there is need, then the awareness of this need, options are searched for, and upon applying subjective or objective criteria the decision is taken to purchase a product/ service [Cristache, N., Năstase, M., Petrariu, R. and Florescu, M., 2019].

A digital consumer uses the internet efficiently and often, mainly benefiting from social media. Mainly the media channels are used to search information on the products, to purchase and consume the selected products, and also sharing online experience with other consumers [Jolanta Tkaczyk, 2016]

The online environment has a great influence on the consumer's behaviour, and thus three types of purchases may be identified:

1. online information and purchase - modern buyer;

The modern buyer is willing to buy online, is keen on technology and has access to several information sources, keeps abreast with all novelties in the social media, gets information from blogs or forums, looks for reviews on a certain product/service. [Sayabek Ziyadin, Raigul Doszhan, Alex Borodin, Aizhan Omarova, and Aigerim Ilyas, 2019]

\section{2. online information and physical purchase - pessimistic buyer;}

The pessimistic buyer does not fully trust online purchase, gathers information on a certain product/service, but does not order it online, but in a physical store, as he is afraid that the product ordered 
may not be like the one on the site, or that he may lose the money and not get the product, or the size could be wrong, or other aspects pertaining to the_14 level of his expectations. [Susan Horner, John Swarbrooke, 2016]

\section{3. offline information and Internet purchase - opportunistic buyer}

The opportunistic buyer first goes to the shop, studies prices, checks out models, sizes, and other features, then it looks for the product online on various sites in order to secure the lowest price, completing the purchase that seems the most attractive (it often happens for sports items, the customer goes to the 4 store, tries out the sports shoes, checks the price and the size and then orders online at the lowest price). [Cristela Maia Bairrada, Arnaldo Coelho, Viktoriya Lizanets, 2019]

According to Kotler, in the decision making process an individual may play five roles:

- $\quad$ initiator - the individual who first suggests buying a certain product;

- $\quad$ influencer - the individual whose opinions or advice influences the decision;

- decider - the individual who decides the components of the purchase decision;

- $\quad$ buyer - the individual making the purchase;

- $\quad$ user - the individual actually using the product. [Ph. Kotler, 2007]

In the online environment the decision making process may be transposed as follows:

1. first the need awareness occurs, as this need may appear before searching various sites or even during the search for another product/service, as an individual's subconscious may be influenced while watching an advertisement;

2. in real time a comparison is performed for the favourite product in terms of price, display manner, availability and delivery time;

3. an online store is selected and the offers are analysed;

4. a certain brand is searched for, and that particular product is ordered;

5. the online purchase decision may be finalized according to certain aspects: site interface, distributor's reputation, acceptable price, positive reviews;

6. after use the post-purchase analysis is performed;

7. if the customer is satisfied he will become a loyal customer.

The need may be functional or aesthetic. In the case of the functional need, the consumer strongly feels the need, lack, discomfort, and his good activity, organization or existence greatly depends on purchasing that product. [Isaac K. Ngugi, Helen O'Sullivan, Hanaa Osman, 2020]

The aesthetic need arises when he wants to be fashionable, or belong to a group; it stimulates mood and the emotional side. [Mark Coeckelbergh, 2019] The purchasing decision is made faster online than offline, and the company, through its marketing team, should take into account several variables: research intensity, research influence, and option assessment. [Kit Smith, 2016]

Thus, the purchase decision depends on these variables as follows:

1. research intensity number of sites visited to visualize the same product; number of advertisements for product $\mathrm{x}$; number of positive reviews in the online environment for the product/service in question;

number of satisfied customers identified by reviews;

- $\quad$ number of sites evaluated for the same product $\mathrm{x}$;

- $\quad$ time allotted to searching on each site.

2. Research influence

- Which are the top advertisements that are deemed as pivotal in influencing the purchase decision?

- Which are the most appreciated sites where product $\mathrm{x}$ can be found?

- Which are the advertising campaigns with the greatest impact on the customer?

- What are the values assigned to researching product $\mathrm{x}$ shown by multimedia elements?

- What is the assessment of site research?

- What will influence the choice decision of a site?

- What are the elements influencing the purchase decision of product $\mathrm{x}$ ?

3. Option assessment

- Is an arrangement by order of preference of the sites possible?

- What is the perception order of the advertisements for product $\mathrm{x}$ ?

- What is the assessment of the information posted on sites?

- Is it possible to have a top of preferred options?

- Were all aspects relevant in making a decision?

\section{Stages of online purchase upon completing the decision-making process:}

The online purchase process is faster than offline trade, and the company must have accurate information on the targeted audience. [Sumesh Dadwal,Vipin Nadda, 2015] 
The marketing team will analyse aspects pertaining to: site, users' expectancies, variants made available by the company and order assessment. [Viorel Iulian Tănase, Ruxandra Victoria Paraschiv, 2019]

At each stage of the online purchase the marketing team will gather information by minute research to catch the customer's interest, so that he becomes a loyal customer in the end.

a) the stage of online pre-purchase $=$ information

it is my opinion that there are various factors influencing the consumer's behaviour, and the market research company may find the customers' opinion so that to be able to attract them in the future. Thus, the following factors were taken into account:

1. aspects of the targeted site

- Is the information useful?

- Is the site trustworthy? (the reviews are very important)

- Does the site have a peculiar aspect?

- Is it different from other sites by graphics and style?

- Do the pages load fast?

- Is there a home page button?

- Is it professionally organized?

2. aspects regarding the user

- Does he trust what is being offered?

- What would a customer expect from the company site?

- How would the user be impressed? By graphics, special design, the manner whereby the company responds to the audience?

- Has he looked for similar products on the site so far?

- Is there a search history?

- $\quad$ Does he like the site? Also promoting it to relatives, or adding it in comments on social media

- Has he added any product to the favourites list?

- Has he requested more information through webchat?

- Is the site safe? Would the customer order from the site?

- Was he going to order the product, adding it to the cart even if eventually he did not order it?

b) the purchase stage $=$ information processing

- What are the online options I can choose from?

- Is there any other site providing a better variant of the product/service?

- Is there a site promoting the same product/service at a lower price?

- Is it possible to make a top of the search and the information found?

- Which search has yielded the best information?

c) the post-purchase stage $=$ result

- What was the purchase experience like?

- How do I assess the online purchase I have made?

- Is the user active in the online environment and leave a review?

- Will he buy again?

- Can marks be assigned to the stages of online purchase? (information - on the site, social networks, reviews; information submission; customer support; delivery - delivery time, the manner of product receipt - deteriorated, not up to standard).

Also, there are several subjective factors that may influence customer behaviour, swaying the purchase decision:

1. The fear that the product will be out of stock/ the buyer will miss out - trusting buyer; used phrases:

- don't miss this unique opportunity!

- Only the first 10 get the promotional code!

- $\quad$ The first 5 get a 3\%voucher!

2. Getting a free product when ordering online products worth $\mathrm{x}$ - the bounty hunter buyer; phrases used:

- half price only now!

- Bonus a phone stand!

- $\quad$ Pay for 3 , get 4 !

3. The idea that he will win the product at a right, transparent price, comparable to other offersobjective determined buyer; phrases used:

- No transport fees!

- The price is transparent!

- Compare our low price to others!

4. Turning the dream into the reality of acquiring possession of the product - idealistic buyer; phrases used: 
- This car can be yours!

- You deserve this product!

- Live your dream!

The purchase decision, both online and offline, may be planned, momentary, or arise whenever the need/ consumer issue occurs. [Netmark's 2016]

\section{Benefits of online purchase:}

Due to the Internet companies can sell their products through online stores, and since competition is fierce, more often than not it is essential to lower the price. [Duangruthai Voramontri, Leslie Klieb, 2019]

Site differentiation, ordering ease, discounts, promoting unique offers and fast delivery are all aspects to be taken into account in the strategy of attracting the targeted audience. [Carmen Ioana IUHOS, Carmen BAL, 2018]

In the online environment the company is easier to promote by:

$\rightarrow$ Access to a wide range of products/ services;

$\rightarrow$ Customer service providing real-time information to customers (the web chat button may be posted on the site);

$\rightarrow$ After the product is delivered, a review or an opinion may be requested by e-mail;

$\rightarrow$ There is no geographical limitations on the purchase, the order will be delivered anywhere, no matter the country of city of delivery;

$\rightarrow$ Time saving;

$\rightarrow$ The possibility to make a real-time comparison of the prices of products/ offers;

$\rightarrow$ The large amount of information provided favours the purchase;

$\rightarrow$ The presence of a high number of offers makes the prices much more competitive;

$\rightarrow$ The comfort of the purchase, eliminating the physical presence of the customer in the store.

But there are also aspects preventing certain individuals from making online purchases:

- Lack of safety regarding the confidentiality of personal data on certain sites;

- Safety of online transactions;

- Lack of trust in the product ordered being the desired one;

- The physical evaluation of the product quality cannot be performed;

- The risk of losing the money.

The product or service in the online environment may acquire a much higher value if the emphasis is laid on interactivity, and thus fast receipt of the product and favourable reviews may have a much greater impact. [T. Sreerekha, R. Saranya, V. S. Prabhu, 2019]

The multimedia elements may present the product in a manner able to impress the customer.

In the online environment, organizations: make their presence known; create new business contacts; provide information on the company's activity, products, related services; increase notoriety; publish realtime advertisements and information; sell products; increase the market share; keep in touch with customers, maintain a correspondence with them; stay connected with the teams of the sales department; penetrate new markets; ensure business continuity. [Electra Mitan, 2019]

\section{Aspects influencing online purchases}

- The fear of losing money, time, or even the product as the stock is limited;

- Obtaining other free products in addition to the purchased ones;

- Fulfilling a desire and entering a certain category;

- The product/service is obtained in a far easier manner, without wasting time shopping.

Despite its apparent ease and rapidity, Internet marketing is not easy to do without formal training and education. The online space is full of cultural, legal and financial traps. [Marieke de Mooij, 2019]

Traditional strategies are not directly transferred on the web, as customers have different challenging expectations. [Alex Jones, Anna H Malczyk, Justin Henley Beneke, 2011]

\section{Customer motivations and expectations in the online environment}

Consumer migration from the offline to the online environment may be explained by the model of online consumer motivations, known as the $6 \mathrm{C}$ model. The $6 \mathrm{C}$ model includes the following motivations: [Dobre C., Milovan A. M., 2009]

1. Content - through content the sites provide information helping the customer make the purchase decision. The content should be as interactive as possible, well structured, and relevant from the informational point of view.

2. Customization - a customized site will always draw attention in comparison to one designed for a less definite audience. The content will be customized through the webpage, posting a history, offer emails.

3. Community (communities created by means of social networking) - they are created through the customers who are active in the social media networks, and share opinions on the products/services used, write reviews or comments. [Rebeca Perren, Robert V. Kozinets 2018] 
4. Convenience - the online consumer can choose the product he wants by maki8ng real-time comparisons at any given time of the day and week. Through this option customers may place orders and select that products be delivered at their house. Product selection and comparison, and delivery selection are made in real time, and all that is necessary is the Internet.

5. Choice - the Internet provides the biggest online store, products and services can be compared, and as a result of the comparison the variants have known advantages and disadvantages, and so the product is selected.

6. Cost reduction - costs are cut down as certain employee and storage expenses will be eliminated, but the users expect to increase speed finding the desired products, making comparisons, receiving usage/delivery terms, ensuring the safety of their personal data and a proper delivery policy and getting answers to their questions.

In the information age, business can be done with anyone (anyone can be a customer), anytime (24/7 all year round) and anywhere. [Electra Mitan, Ana-Maria Borozan, 2014]

6. Qualitative research trough the interview technique on customer behaviour in the online environment

Defining the research topic: customer behaviour in the online environment

Name known to subjects: internet use in daily activities

Subjects: the administrative and secretariat personnel at the Faculty of Economy and Business Administration, Galati

\section{Research hypotheses}

- Most respondents use the internet on a daily basis.

- Most respondents use the internet for online applications.

- In general, the respondents use the internet just for social networks.

- A part of the respondents only use the internet at the office.

\section{Research objectives}

1. Evaluating the behaviour of online consumers;

2. Identifying the motivations of internet use;

3. Finding the expectations of the online customer;

4. Identifying the implications of social platforms in digital marketing.

\section{The interview}

The present research focuses on the analysis of customer behaviour in the online environment, checking the frequency of internet use for daily activities, the motives of internet use and the impact of social platforms on the economy.

Objective 1. Evaluating consumer behaviour in the online environment

a) Would you be able to make do without Internet for 7 days?

b) In cases of maximum necessity, would you contract a loan through online banking?

c) Have the advertisements for the lajumate.ro application made you curious to visit the site?

d) Do relatives' /friends' recommendations matter in choosing products bought online? Objective 2. Identifying the motivations of internet use

a) To what purpose do you most often use the Internet?

b) How much time do you spend daily on social networks?

c) Have you used the internet for ridesharing applications? Objective 3. Setting the expectations of the online consumer

a) Which online information source seems the most reliable?

b) What would be a good advertisement for a site for renting special event outfits?

c) What do you think should be stressed in online advertisements to increase the number of subscriptions to online libraries?

d) Do you think there are benefits in using online applications (Internet banking, UBER, OLX etc.)? Objective 4. Identifying implications of social platforms in digital marketing

a) Are online social platforms useful in the services sector?

b) Would you resort to bikesharing or ridesharing to get to work?

c) Have you visited the OLX platform? 


\section{Content analysis}

\begin{tabular}{|c|c|c|c|c|c|c|}
\hline $\begin{array}{c}\text { Topics } \\
\text { discussed }\end{array}$ & Subject 1 & Subject 2 & Subject 3 & Subject 4 & Subject 5 & $\begin{array}{c}\text { Horizontal } \\
\text { analysis }\end{array}$ \\
\hline \multicolumn{7}{|c|}{ 1. Evaluating consumer behaviour in the online environment } \\
\hline $\begin{array}{l}\text { Life without } \\
\text { Internet }\end{array}$ & 1. yes & 2. No & 2. No & 2. No & 2. No & $\begin{array}{l}\text { 1.= once } \\
2 .=4 \text { times }\end{array}$ \\
\hline $\begin{array}{l}\text { Contracting a } \\
\text { loan through } \\
\text { online } \\
\text { banking }\end{array}$ & $\begin{array}{l}\text { 1. I do not trust } \\
\text { the banking } \\
\text { system }\end{array}$ & $\begin{array}{l}\text { 2. yes, I use } \\
\text { Internet } \\
\text { banking }\end{array}$ & $\begin{array}{l}\text { 2. Yes, I have } \\
\text { already taken } \\
\text { a loan through } \\
\text { the application }\end{array}$ & $\begin{array}{l}\text { 1. No, I would } \\
\text { resort to } \\
\text { family or } \\
\text { friends }\end{array}$ & $\begin{array}{l}2 . \text { Yes, I } \\
\text { would try }\end{array}$ & $\begin{array}{l}1 .=2 \text { times } \\
2=3 \text { times }\end{array}$ \\
\hline $\begin{array}{l}\text { Advertise- } \\
\text { ments for } \\
\text { lajumate.ro }\end{array}$ & $\begin{array}{l}\text { 1. I do not enter } \\
\text { such sites }\end{array}$ & $\begin{array}{l}\text { 2. Yes, I looked } \\
\text { for a second- } \\
\text { hand car }\end{array}$ & $\begin{array}{l}\text { 2. Yes, I look } \\
\text { for vintage } \\
\text { items }\end{array}$ & $\begin{array}{l}\text { 2. yes, to } \\
\text { compare } \\
\text { product prices }\end{array}$ & $\begin{array}{l}\text { 1. I am not } \\
\text { interested } \\
\text { in such sites }\end{array}$ & $\begin{array}{l}1 .=2 \text { times } \\
2 .=3 \text { times }\end{array}$ \\
\hline $\begin{array}{l}\text { Friends' } \\
\text { recommenda } \\
\text { tions in } \\
\text { online } \\
\text { purchases }\end{array}$ & $\begin{array}{l}\text { 1. No, I can } \\
\text { choose the } \\
\text { product myself }\end{array}$ & $\begin{array}{l}\text { Yes, but I also } \\
\text { look for } \\
\text { reviews }\end{array}$ & $\begin{array}{l}\text { Yes, mostly } \\
\text { friends who } \\
\text { order often }\end{array}$ & $\begin{array}{l}\text { Yes, I often } \\
\text { seek friends' } \\
\text { advice }\end{array}$ & $\begin{array}{l}\text { Yes, as a } \\
\text { second } \\
\text { opinion } \\
\text { matters }\end{array}$ & $\begin{array}{l}\text { 1. }=\text { once } \\
2 .=4 \text { times }\end{array}$ \\
\hline \multicolumn{7}{|c|}{ 2. Identifying the motivations for internet use } \\
\hline $\begin{array}{l}\text { Reason for } \\
\text { internet use }\end{array}$ & $\begin{array}{l}\text { 1. office activity } \\
\text { 2. social } \\
\text { networks }\end{array}$ & $\begin{array}{l}\text { 1. office } \\
\text { activity } \\
\text { 3. online apps } \\
\text { 4. } \\
\text { entertainment }\end{array}$ & $\begin{array}{l}\text { 1. office } \\
\text { activity } \\
\text { 5. online } \\
\text { purchases } \\
\text { 2. social } \\
\text { networks } \\
\text { 3. online apps }\end{array}$ & $\begin{array}{l}\text { 1. office } \\
\text { activity } \\
\text { 2. social } \\
\text { networks } \\
\text { 5. online } \\
\text { purchases }\end{array}$ & $\begin{array}{l}\text { 1. office } \\
\text { activity } \\
\text { 3. online apps } \\
\text { 5.online } \\
\text { purchases }\end{array}$ & $\begin{array}{l}1 .=5 \text { times } \\
2 .=3 \text { times } \\
3 .=3 \text { times } \\
4 .=\text { once } \\
5 .=3 \text { times }\end{array}$ \\
\hline $\begin{array}{l}\text { Daily amount } \\
\text { of time spent } \\
\text { on the } \\
\text { Internet }\end{array}$ & 1. one hour & $\begin{array}{l}\text { 2. between } \\
\text { one and two } \\
\text { hours }\end{array}$ & $\begin{array}{l}\text { 3. over two } \\
\text { hours }\end{array}$ & 1. one hour & $\begin{array}{l}\text { 3. more than } \\
\text { two hours }\end{array}$ & $\begin{array}{l}1 .=2 \text { times } \\
2 .=\text { once } \\
3 .=2 \text { times }\end{array}$ \\
\hline $\begin{array}{l}\text { Using the } \\
\text { internet for } \\
\text { ridesharing }\end{array}$ & $\begin{array}{l}\text { 1. no, I do not } \\
\text { even know how } \\
\text { the application } \\
\text { works }\end{array}$ & $\begin{array}{l}\text { 2. yes, when I } \\
\text { am in cities } \\
\text { where the } \\
\text { UBER system } \\
\text { is already } \\
\text { implemented }\end{array}$ & $\begin{array}{l}\text { 2. yes, I last } \\
\text { used it when I } \\
\text { was in Cluj }\end{array}$ & 1. No, never & $\begin{array}{l}\text { 1. I do not } \\
\text { know about } \\
\text { such apps, it } \\
\text { is the first } \\
\text { time I hear } \\
\text { about them }\end{array}$ & $\begin{array}{l}1 .=3 \text { times } \\
2 .=2 \text { times }\end{array}$ \\
\hline \multicolumn{7}{|c|}{ 3. Setting expectations for online consumers } \\
\hline $\begin{array}{l}\text { Online } \\
\text { sources of } \\
\text { information }\end{array}$ & $\begin{array}{l}\text { 1. search } \\
\text { engines }\end{array}$ & $\begin{array}{l}\text { 1. search } \\
\text { engines } \\
\text { 2. open } \\
\text { platforms } \\
\text { (www.e- } \\
\text { școala.ro) }\end{array}$ & $\begin{array}{l}\text { 1. search } \\
\text { engines } \\
\text { 2. information } \\
\text { platforms/ } \\
\text { open libraries } \\
\text { (scribd) }\end{array}$ & $\begin{array}{l}\text { 1.search } \\
\text { engines } \\
\text { 2. information } \\
\text { platforms/ } \\
\text { open libraries } \\
\text { (issuu) }\end{array}$ & $\begin{array}{l}2 . \\
\text { information } \\
\text { platforms/ } \\
\text { open } \\
\text { libraries } \\
\text { (scribd, } \\
\text { issuu) }\end{array}$ & $\begin{array}{l}1 .=4 \text { times } \\
2 .=4 \text { times }\end{array}$ \\
\hline $\begin{array}{l}\text { Advertiseme } \\
\text { nts for a site } \\
\text { for renting } \\
\text { formal wear }\end{array}$ & $\begin{array}{l}\text { 1. guaranteed } \\
\text { quality } \\
\text { 2. unique } \\
\text { outfits for } \\
\text { special persons } \\
\text { 3. reasonable } \\
\text { prices }\end{array}$ & $\begin{array}{l}\text { 2. for a special } \\
\text { occasion we } \\
\text { provide } \\
\text { unique outfits }\end{array}$ & $\begin{array}{l}\text { 1. to } \\
\text { emphasize } \\
\text { quality }\end{array}$ & $\begin{array}{l}\text { 3. reasonable } \\
\text { prices }\end{array}$ & $\begin{array}{l}\text { 2. to } \\
\text { emphasize } \\
\text { the outfit }\end{array}$ & $\begin{array}{l}\text { 1.= } 2 \text { times } \\
2 .=3 \text { times } \\
\text { 3.= } 2 \text { times }\end{array}$ \\
\hline $\begin{array}{l}\text { Subscriptions } \\
\text { for on-line } \\
\text { library }\end{array}$ & $\begin{array}{l}\text { 1. ease } \\
\text { 2. affordable } \\
\text { price } \\
\text { 3. wide range of } \\
\text { online books } \\
\text { 4. paper saving }\end{array}$ & $\begin{array}{l}\text { 1.ease } \\
\text { 4. paper } \\
\text { saving }\end{array}$ & $\begin{array}{l}\text { 2. affordable } \\
\text { price }\end{array}$ & $\begin{array}{l}\text { 3. wide range of } \\
\text { online books } \\
\text { 4. paper saving }\end{array}$ & $\begin{array}{l}\text { 1. ease } \\
\text { 4. paper } \\
\text { saving }\end{array}$ & $\begin{array}{l}1 .=3 \text { times } \\
2 .=2 \text { times } \\
3 .=2 \text { times } \\
4 .=4 \text { times }\end{array}$ \\
\hline $\begin{array}{l}\text { Benefits of } \\
\text { using online } \\
\text { apps }\end{array}$ & $\begin{array}{l}\text { 1. time saving } \\
\text { 3. ease }\end{array}$ & $\begin{array}{l}\text { 2.real-time } \\
\text { offer } \\
\text { comparison } \\
\text { 3.ease } \\
\end{array}$ & $\begin{array}{l}\text { 2. fast search } \\
\text { 4. fair price } \\
\text { (UBER) }\end{array}$ & $\begin{array}{l}\text { 5. no } \\
\text { administrative } \\
\text { costs (banking) }\end{array}$ & $\begin{array}{l}\text { 1. time } \\
\text { saving } \\
\text { 3. ease }\end{array}$ & $\begin{array}{l}\text { 1.= } 2 \text { times } \\
2 .=2 \text { times } \\
3 .=3 \text { times } \\
4 .=\text { once }\end{array}$ \\
\hline
\end{tabular}




\begin{tabular}{|c|c|c|c|c|c|c|}
\hline $\begin{array}{c}\text { Topics } \\
\text { discussed }\end{array}$ & Subject 1 & Subject 2 & Subject 3 & Subject 4 & Subject 5 & $\begin{array}{c}\text { Horizontal } \\
\text { analysis }\end{array}$ \\
\hline & & & & & & $5 .=$ once \\
\hline \multicolumn{7}{|c|}{ 4. Identifying implications of social platforms in digital marketing } \\
\hline $\begin{array}{l}\text { Usefulness of } \\
\text { social } \\
\text { platforms }\end{array}$ & 1. lower costs & $\begin{array}{l}\text { 1. lower costs } \\
2 . \\
\text { Saving } \\
\text { resources by } \\
\text { sharing } \\
\text { objects } \\
\text { 3. fast service } \\
\text { search }\end{array}$ & $\begin{array}{l}\text { 1. lower costs } \\
\text { 4. real-time } \\
\text { discussions } \\
\text { with the other } \\
\text { business } \\
\text { partners }\end{array}$ & $\begin{array}{l}\text { 2. Saving } \\
\text { resources by } \\
\text { sharing } \\
\text { objects }\end{array}$ & $\begin{array}{l}\text { 1. lower costs } \\
\text { 3. fast service } \\
\text { search }\end{array}$ & $\begin{array}{l}1 .=4 \text { times } \\
2 .=2 \text { times } \\
3 .=2 \text { times } \\
4 .=\text { once }\end{array}$ \\
\hline $\begin{array}{l}\text { bikesharing/ } \\
\text { ridesharing } \\
\text { apps }\end{array}$ & $\begin{array}{l}\text { 1. no, as I drive } \\
\text { to work }\end{array}$ & $\begin{array}{l}\text { 2. yes, } \\
\text { occasionally }\end{array}$ & $\begin{array}{l}2 . \text { I would like } \\
\text { to bike to } \\
\text { work }\end{array}$ & $\begin{array}{l}2 \text {. I would } \\
\text { occasionally } \\
\text { resort to } \\
\text { ridesharing }\end{array}$ & $\begin{array}{l}\text { 2. yes, as I } \\
\text { would benefit } \\
\text { from quality } \\
\text { services }\end{array}$ & $\begin{array}{l}1 .=\text { once } \\
2 .=4 \text { times }\end{array}$ \\
\hline OLX & $\begin{array}{l}\text { 1. no, I usually } \\
\text { buy only from } \\
\text { certain sites }\end{array}$ & $\begin{array}{l}\text { 2. yes, I enter } \\
\text { quite often }\end{array}$ & $\begin{array}{l}2 . \text { yes, the ads } \\
\text { are very well } \\
\text { organized }\end{array}$ & $\begin{array}{l}\text { 2. I } \\
\text { occasionally } \\
\text { access the site }\end{array}$ & 2. yes, once & $\begin{array}{l}1 .=\text { once } \\
2 .=4 \text { times }\end{array}$ \\
\hline \multicolumn{7}{|c|}{ Vertical analysis } \\
\hline
\end{tabular}

\section{Vertical analysis}

\section{Subject 1 - age $=54$, urban background, female}

She considers that she can live without Internet for 7 days as she does not frequently use online applications. She would not take a loan through online banking, as she does not have the app in the phone, but instead would go directly to a bank. She does not access sites like OLX or lajumate.ro. When shopping online she makes her own decisions. Internet is used most often for office activity (reading/writing emails), and sometimes for social networks, but the time spent online is one hour daily at most.

She has never used the ridesharing app and does not know how it works. The information source she most often uses is search engines. A good advertisement for formal wear renting sites that may impress her should focus on quality, price, and unique outfits. She would subscribe to an online library for ease of access and book variety, paper saving, but the price is also important.

She considers that by using online social platforms costs may be reduced. She drives to work, so she would not be interested in using ridesharing apps. She does not access OLX as she shops on the sites that she already knows.

\section{Subject 2 - age $=46$, urban background, female}

She thinks she could cope for 7 days without Internet, and if she needed a loan she would take one by the Internet banking application. She accesses the OLX application quite often to search for various offers, and when she goes shopping online she takes into account her friends' opinions, as well as the reviews.

She makes use of the internet at the office, and for on-line banking apps and entertainment. She uses the internet for 2 hours daily at most, and she is familiar with the ridesharing UBER application which she used when she was in Brașov. Search engines and open platforms are considered as the best online information sources. She would be attracted by an advertisement focusing on a special outfit. She would be willing to buy a subscription to an online library, the advantages being ease of access, as well as saving paper for printed books.

By means of online applications she may compare offers in real time and that seems much more comfortable. She uses online social platforms as she believes in saving resources by sharing objects, costs may be lower, and products/services may be found more easily. She accesses OLX quite often to check the offers.

\section{Subject 3 - age $=42$, male, urban background}

He would not be able to give up Internet for 7 days, and if he needed money fast he would take a loan through the online banking application, and he also has one taken online. He looks for vintage items on platforms like OLX or lajumate.ro.

He does not hesitate to ask for advice from the friends who order more often when he decides to go online shopping. He uses the internet for online applications, social media and office activity, and he surfs the 
web for more than 2 hours. He has already used the ridesharing app when he was in Cluj. The online information sources he resorts to are search engines and information platforms. He considers that the sites for renting formal outfits should use ads stressing quality.

He would use a subscription for an online library if it had an affordable price. He is interested in using apps like UBER for the right price, and an advantage would be the ready access to the desired service. He sees social platforms as useful as they have low costs and he may talk in real time to the other business partners. He would be willing to use ridesharing or bikesharing apps. He considers that OLX advertisements are well organized.

\section{Subject 4 - age $=47$, female, urban background}

She would not be able to cope for 7 days without Internet, and if in the future she would need money urgently, she would resort to friends, not to the online app to take a loan. She accesses OLX to compare prices for various products/services, and when purchasing online she also asks her friends for advice. She uses the internet at the office, for social platforms and for online shopping.

The time she spends online is one hour daily, she has not yet used the ridesharing app, and she thinks that the most credible information sources are search engines and information platforms. She would appreciate an outfit renting ad as good if it focused on affordable prices. The ads for online library should focus on the wide range of books and paper saving. She uses online apps, and an important advantage is the lack of administration costs.

Social platforms are useful as they contribute to sharing resources. If Uber could be implemented in Galați she would be willing to replace taxis with the ridesharing app. She occasionally accesses OLX.

\section{Subject 5 - age $=47$, female, urban background}

She says she would not be able to cope 7 days without Internet, and in case she needed money she would be willing to get a loan through online banking. She is not interested in sites like lajumate.ro or OLX. When ordering online she also asks for the opinion of her friends. She uses the internet for office activities, online apps and sometimes online shopping.

She uses the Internet for more than two hours daily, but does not know about ridesharing apps, learning of them now. Information platforms and open libraries seem to be the most trustworthy sources of online information. A good advertisement for an outfit renting site should focus on a special outfit. She would agree to accessing a subscription for an online library, and the benefits of this service would be paper saving and the reader's comfort. Online apps provide consumers with comfort and save time. Online social platforms are useful for the services sector as they have low costs, and the services may be found more readily. She would be willing to use the ridesharing app. Regarding the olx site, she does not quite use it, looked at it only once.

\section{Conclusions of the research by the interview technique}

The subjects involved in this qualitative research are aged between 42 and 54, 4 female and 1 male.

The analysis revealed that the 54 year-old is more reluctant to using the internet to a financial purpose. Also, she rather seldom accesses sites like OLX or lajumate.ro. she considers that the internet is a useful tool in office activity, but she would not dare access a loan through online banking. On the contrary, she would subscribe to an online library.

Hence, her greatest fear would be the financial risk; if the bikesharing application were implemented in Galați, she would not try it.

At the opposite pole is situated subject 3 (42), who is the most open-minded in point of using the internet for daily activities, and is familiar with ridesharing/bikesharing apps. He simplifies his daily tasks by using the internet. Individuals of this type may be the favourite customers for lateral exchange markets lateral.

Subjects 2, 4, and 5 gave similar answers, as they constitute the majority of internet users, both in daily activities and online entertainment and shopping. They would not be opposed to ridesharing or bikesharing apps, and access the sites like OLX or lajumate.ro to check the offers. This type of individuals would be easily persuaded to be part of lateral markets if the operating system is clearly explained to them. The subject 1 type, who is more reluctant, would agree to this system of online markets only by the power of the example, i.e. by seeing it work with friends first, and even if not fully convinced, it is worth a try.

\section{Conclusions}

Online information sources have quite an impact on the purchase decision taken by the consumer when looking for a product, who thus has the possibility to evaluate several similar options by subjective or objective factors. The consumer's behaviour is influenced by several factors, such as: social, psychological, economic, cultural, etc. [Cristache N, 2008] 
The benefits of online purchases are multiple, from access to a wide range of products, the possibility to compare products according to a variety of factors (price, delivery, colours available, etc.) to online assistance through the web chat button.

The first impressing when entering the store is replaced by the first impression when accessing the site, and what matters is the manner of data collection, the ease of use, the site graphics and the manner of product display. In the online environment customer loyalty is gained faster and easier, all the sites visited for that particular product are analysed, sites are sorted out, and the comparison is directly performed based on certain criteria, the online purchase is made, then it is assessed, and finally customer loyalty is achieved or not.

The online company takes into account the next behavioural reactions, expectations and intentions: communication in mass-media by reviews and comments, loyalty and repeated purchase.

The process of online acquisition performed by the buyer has the following implications: capturing interest by online presentation and multimedia effects, the symbol through status provided to the customer, satisfaction through the consumer's psychological and emotional state, the risk perceived by the customer when buying online, and finally the confidence that he made the best choice.

Online acquisitions give the customer visibility, the idea that he may share the benefits obtained with others via the Internet or he may feel special. Online satisfaction presupposes evaluation through reviews and comments after several purchases from the same site, and subsequently customer loyalty is targeted.

Satisfaction according the expectation level may trigger indifference or loyalty. Expectations depend on product performance, the information delivered, and the ease of product evaluation. The strategy of attracting customers will be better implemented if there is knowledge about the customer's behaviour in the online environment, his expectations, the assessment manner and the site evaluation criteria.

\section{References}

1. Alex Jones, Anna H Malczyk, Justin Henley Beneke, 2011 - Internet Marketing: a highly practical guide to every aspect of Internet marketing, 2011

2. Carmen Ioana IUHOS, Carmen BAL, 2018 - Transformările marketingului în raport cu evoluția tehnologică, a XVIII-a Conferință internațională - multidisciplinară „Profesorul Dorin Pavel - fondatorul hidroenergeticii românești”, Cluj-Napoca, 2018.

3. Cristache Nicoleta, 2008 - Comportamentul consumatorului, Editura Cartea Universitară Bucuresti, 2008.

4. Cristache, N., Năstase, M., Petrariu, R. and Florescu, M., 2019. Analysis of Congruency Effects of Corporate Responsibility Code Implementation on Corporate Sustainability in Bio-Economy. Amfiteatru Economic, 21(52), pp. 536-553.

5. Cristela Maia Bairrada, Arnaldo Coelho, Viktoriya Lizanets, 201] - The impact of brand personality on consumer behavior: the role of brand love, 2019.

6. Dobre C., Milovan A. M., 2009 - Dobre C., Milovan A. M., Marketing online și social media, Editura C.H. Beck, București, 2009.

7. Duangruthai Voramontri, Leslie Klieb, 2019 - Impact of social media on consumer behaviour, 2019.

8. Electra MITAN, 2019 - Transformarea digitală a marketing-ului, Romanian Journal of Information Technology and Automatic Control, Vol. 29, No. 3, 79-96, 2019.

9. Electra Mitan, Ana-Maria Borozan, 2014 - Sistem interactiv de marketing pe Internet, Revista Română de Interacţiune Om-Calculator, 2014.

10. Epuran, Gheorghe; Bianca Tescașiu, Raluca Dania Todor, Karin-Andreea Sasu, Nicoleta Cristache (2017): Responsible Consumption Source of Competitive Advantages and Solution for Tourist Protection, Amfiteatru Economic Journal, ISSN 2247-9104, The Bucharest University of Economic Studies, Bucharest, Vol. 19, Iss. 45, pp. 447-462.

11. Isaac K. Ngugi, Helen O'Sullivan, Hanaa Osman, 2020 - Consumer Behaviour in Food and Healthy Lifestyles: A Global Perspective, Editor CABI, 2020.

12. Jolanta Tkaczyk, 2016 - Digital Consumer: Trends and Challenges, 2016.

13. Kit Smith, 2016] - How to Understand and Influence Consumer Behavior, Editor Routledge, 2016.

14. Marieke de Mooij, 2019 - Consumer Behavior and Culture: Consequences for Global Marketing and Advertising, Editor SAGE, 2019.

15. Mark Coeckelbergh, 2019 - Artificial Intelligence, Responsibility Attribution, and a Relational Justification of Explainability, Science and Engineering Ethics, 2019.

16. Netmark's 2016 - Guide to The 6 Fundamentals of Digital Marketing, 2016.

17. Ph. Kotler, 2007 - Managementul Marketingului, Editura Teora București, 2007.

18. Rebeca Perren, Robert V. Kozinets 2018 - Lateral Exchange Markets: How Social Platforms Operate in a Networked Economy, 2018.

19. Sayabek Ziyadin, Raigul Doszhan, Alex Borodin, Aizhan Omarova, and Aigerim Ilyas, 2019 - The role of social media marketing in consumer behaviour, E3S Web of Conferences 135, 04022, 2019.

20. Sumesh Dadwal,Vipin Nadda, 2015 - Social media marketing, author profiles for this publication at: https://www.researchgate.net/publication/297056488.

21. Susan Horner, John Swarbrooke, 2016 - Consumer Behaviour in Tourism,2016.

22. T. Sreerekha, R. Saranya, V. S. Prabhu, 2019 - Consumer Behaviour in Online Shopping, International Journal of Trend in Scientific Research and Development, Volume 3 Issue 5, August 2019.

23. Viorel Iulian Tănase, Ruxandra Victoria Paraschiv, 2019 - Digitizare, digitalizare și transformare digitală, Institutul de Filosofie și Psihologie "Constantin Rădulescu-Motru" al Academiei Române, 2019. 